\title{
DAERAH RISIKO COVID-19 DI KABUPATEN BADUNG
}

\author{
Sugianto, Made Agus \\ ${ }^{1}$ Badan Penelitian dan Pengembangan Kabupaten Badung \\ Korespondensi: agussugianto146@gmail.com
}

\begin{abstract}
Background: The report of the Covid-19 Task Force in Badung Regency shows an increasing trend of Covid-19 cases in Badung Regency from March to August 2020. Purpose: the purpose of this study is to obtain a map of the Covid-19 risk areas in the Badung Regency. Methods: the method in this study is a descriptive-analytic with a cross-sectional study design. This research was conducted in Badung Regency for two months from 15 July to 15 September 2020 using secondary data from the daily reports of the Covid-19 Task Force in Badung Regency from 23 August 2020 to 23 September 2020. Results: the results of the zoning mapping from the Epidemiological aspect showed that 4 sub-districts $(66.6 \%)$ of the 6 subdistricts were the Covid-19 red zones. From the aspect of Regional Capability in Handling Cases of Covid-19 Infection, it shows that all districts are included in the High Response category in handling Covid-19, and from the aspect of Regional Ability to Trace the History of Close Contact of People Infected with Covid-19 it appears that 3 districts $(50 \%)$ are included in the category of areas with moderate ability, while the other 3 sub-districts are included in the category of regions with low ability. Conclusion: Based on the results of this study, it is concluded that the level of the spread of Covid-19 in the Badung Regency is very high, even though the level of readiness of the Government in handling Covid-19 cases is very good. The geography of the area bordering other districts/ cities and high population mobility are suspected to be the triggers for the high number of Covid-19 cases.
\end{abstract}

\section{Keywords: Mapping; Covid-19; Badung Regency}

\begin{abstract}
ABSTRAK
Latar belakang: laporan Satuan Tugas Covid-19 Kabupaten Badung menunjukan tren peningkatan kasus Covid-19 di Kabupaten Badung dari bulan Maret hingga Agustus 2020. Tujuan: tujuan penelitian ini adalah untuk memperoleh gambaran peta daerah risiko Covid-19 di Kabupaten Badung. Metode: metode dalam penelitian ini adalah descriptive analytic dengan desain crosssectional Study. Penelitian ini dilaksanakan di Kabupaten Badung selama dua bulan dari tanggal 15 Juli sampai dengan 15 September 2020 dengan menggunakan data sekunder laporan harian Satuan Tugas Covid-19 Kabupaten Badung dari tanggal 23 Agustus 2020 sampai dengan 23 September 2020. Hasil: hasil pemetaan daerah dari aspek Epidemiologi menunjukan sebanyak 4 kecamatan $(66,6 \%)$ dari 6 kecamatan merupakan zona merah Covid-19. Dari aspek Kemampuan Daerah Dalam Menangani Kasus Infeksi Covid-19 menunjukan bahwa semua kecamatan masuk dalam kategori Respon Tinggi dalam penanganan Covid-19 dan dari aspek Kemampuan Daerah Dalam Melakukan Penelusuran Riwayat Kontak Dekat Orang
\end{abstract}


Yang Terinfeksi Covid-19 nampak bahwa 3 kecamatan (50\%) masuk dalam kategori Daerah Dengan Kemampuan Sedang, sedangkan 3 kecamatan lainnya masuk dalam kategori Daerah Dengan Kemampuan Rendah. Simpulan: berdasarkan hasil penelitian tersebut disimpulkan bahwa tingkat persebaran Covid19 di Kabupaten Badung sangat tinggi, meskipun tingkat kesiapan Pemerintah dalam menangani kasus Covid-19 sangat bagus. Geografis daerah yang berbatasan dengan kabupaten/kota lain serta tingginya mobilitas penduduk di duga sebagai pemicu tingginya kasus Covid-19.

Keywords: Pemetaan; Covid-19; Kabupaten Badung

\section{PENDAHULUAN}

Coronavirus-19 (COVID) telah dinyatakan sebagai pandemi dunia oleh WHO (WHO,2020). Coronavirus adalah zoonosis atau virus yang ditularkan antara hewan dan manusia. Virus dan penyakit ini diketahui berawal di kota Wuhan, Cina sejak Desember 2019. Per tanggal 12 September 2020, jumlah kasus penyakit ini mencapai angka 28.584.459 jiwa yang tersebar di 169 negara dengan jumlah kematian mencapai 917.183 jiwa (Gusgus Tugas Covid 19, 2020). Jumlah kasus Covid 19 di Indonesia sampai dengan tanggal 12 September 2020 mencapai 214.746 kasus degan jumlah kematian mencapai 8.650 orang (4\%). Sedangkan di Provinsi Bali per tanggal yang sama, jumlah kasus Covid 19 mencapai 7.113 kasus dengan angka kematian 168 orang (2,5\%). Demikian pula Kabupaten Badung, jumlah kasus Covid 19 sampai dengan tanggal 12 September 2020 sudah mencapai 1.046 dan sebanyak 28 orang meninggal (Gusgus Tugas Covid 19, 2020).

Di negara kepulauan seperti Indonesia, tingginya mobilitas antarpulau dapat memfasilitasi meluasnya penyebaran penyakit menular dengan cepat. Ada banyak bukti yang menunjukkan pergerakan orang yang terinfeksi coronavirus dari zona merah ke tempat lain lewat pesawat, kapal laut, dan transportasi darat berperan besar dalam penyebaran COVID-19 di banyak negara (Elyazar, dkk, 2020). Hasil survei Dinas Perhubungan Kota Bandung Tahun 2020 menyimpulkan bahwa hanya $20 \%$ masyarakat yang kekawatiran tertular virus Corona, Sementara yang tertinggi adalah khawatir kehilangan pekerjaan (62\%) dan $18 \%$ sisanya kawatir penghasilannya berkurang (Firmansyah, 2020).

Berbagai langkah telah diambil oleh pemerintah dalam mencegah dan mengendalikan peyebaran virus ini. Langkah pencegahan tersebut adalah dengan memantau orang yang memiliki riwayat bepergian di daerah episenter dan 
menelusuri kontak dari pasien yang sudah terinfeksi. Tigkat keberhasilan langkah ini sangat bergantung pada peran serta masyarakat, mulai dari RT/RW, desa, kelurahan, kecamatan, hingga dinas kesehatan dibantu aparat setempat (Gusgus Tugas Covid 19, 2020).

Keputusan Menteri Dalam Negeri Nomor 440-830 Tahun 2020 tentang Pedoman Tatanan Normal baru Produktif dan Aman Corona Virus Desease 2019 Bagi Aparatur Sipil Negara di Lingkungan Kementerian Dalam Negeri dan Pemerintah Daerah. Keputusan Menteri Dalam Negeri ini merupakan pedoman bagi pemerintah daerah dalam memerangi Covid-19 dengan mengklasifikasi wilayahnya dalam beberapa daerah dengan menggunakan indicator kondisi epidemiologi, Kemampuan Daerah Dalam Menangani Kasus Infeksi Covid-19 dan Kemampuan Daerah Dalam Melakukan Penelusuran Riwayat Kontak Dekat Orang Yang Terinfeksi Covid-19.

Dalam menentukan pemetaan epidemologis, daerah dibagi dalam tiga kategori, yaitu hijau, kuning, dan merah. Status zona diukur dari grafik kasus positif, jumlah ODP/PDP, jumlah kematian, dan tingkat penularan langsung ke petugas kesehatan selama 14 hari terakhir. Daerah yang mendapat skor 60-75 menyandang status zona merah, peraih skor 80-95 menjadi zona kuning, dan zona hijau adalah daerah yang meraih skor sempurna 100. Penerapan kebijakan masyarakat produktif dan aman Covid 19 dilakukan pada daerah yang kondisi epidemologisnya berada pada zona aman atau hijau.

Kemudian kemampuan daerah dalam penanganan kesehatan masyarakat diukur dari ketersediaan pelindung komunitas masyarakat, ketersediaan pelindung tenaga medis, sarana dan prasarana medis lainnya, serta perlengkapan pascawafat. Suatu daerah dinilai memiliki respons tinggi jika meraih skor 850-1.000. Peraih skor 500- 850 menyandang status respons sedang. Sementara daerah yang mengumpulkan skor kurang dari 500 dicap sebagai daerah yang punya respons rendah.

Indikator ketiga adalah kemampuan pemda menelusuri kontak pasien, ODP, dan PDP corona. Empat kriteria yang disyaratkan adalah identifikasi orang yang memiliki kontak dekat dengan orang terindikasi corona, data orang terinfeksi corona, pengujian terhadap orang yang memiliki kontak dengan corona, dan 
penerapan serta pengawasan social distancing. Daerah dianggap punya kemampuan tinggi menghadapi corona jika meraih skor 400. Peraih skor 300-375 dimasukkan dalam kategori respons sedang. Sementara sisanya (skor <300) dianggap memiliki respons rendah.

\section{TUJUAN}

Secara umum penelitian ini bertujuan untuk mengetahui gambaran peta daerah Covid-19 di Kabupaten Badung dan tujuan secara khusus adalah untuk mengetahui gambaran peta daerah Covid-19 di Kabupaten Badung berdasarkan aspek epidemiologi, aspek Kemampuan Daerah Dalam Menangani Kasus Infeksi Covid-19 dan aspek Kemampuan Daerah Dalam Melakukan Penelusuran Riwayat Kontak Dekat Orang Yang Terinfeksi Covid-19.

\section{METODE}

Penelitian ini adalah penelitian deskriptif dengan desain crosssectional Study. Penelitian ini dilaksanakan di Kabupaten Badung selama satu bulan yaitu dari tanggal 15 Agustus sampai dengan 15 September 2020. Data sekunder dalam penelitian ini adalah laporan harian Satuan Tugas Covid-19 Kabupaten Badung dari tanggal 16 Agustus sampai dengan 31 Agustus 2020. Data kualitatif dalam penelitian ini adalah hasil wawancara dengan Tim Gugus Tugas Covid-19 Dinas Kesehatan Kabupaten Badung. Instrumen yang digunakan dalam mengklasifikasi peta daerah adalah Keputusan Menteri Dalam Negeri 440-830 Tahun 2020 tentang Pedoman Tatanan Normal baru Produktif dan Aman Corona Virus Desease 2019 Bagi Aparatur Sipil Negara di Lingkungan Kementerian Dalam Negeri dan Pemerintah Daerah.

\section{HASIL}

\section{Aspek Epidemiologi}

Jumlah kasus Covid-19 di Kabupaten Badung menunjukkan peningkatan pada semua kecamatan dalam 14 hari yaitu dari Tanggal 23 Agustus 2020 sampai dengan 5 September 2020. Data kasus Covid-19 dapat dilihat pada grafik 1. 


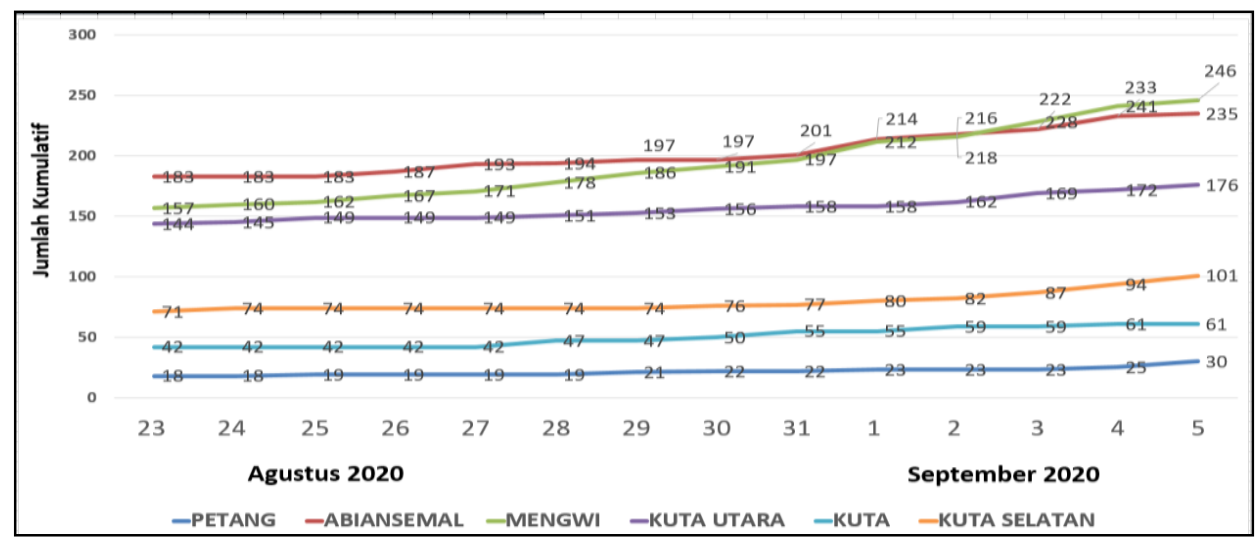

Gambar 1. Grafik kasus Covid-19 di Kabupaten Badung Sumber: Data Satgas Covid-19 Kabupaten Badung yang diolah.

Pada gambar 1 nampak bahwa kasus Covid-19 paling banyak ditemukan di Kecamatan Mengwi (246 kasus), kemudian diikuti oleh Kecamatan Abiansemal (235 kasus), Kecamatan Kuta Utara (176 kasus), Kecamatan Kuta Selatan (101 kasus), Kecamatan Kuta (61 kasus) dan yang paling sedikit di Kecamatan Petang (30 kasus).

Trend jumlah kematian akibat covid-19 di Kabupaten Badung dalam 14 hari, dari Tanggal 23 Agustus 2020 sampai dengan 5 September 2020. Data kasus kematian akibat Covid-19 terlihat pada grafik 2.

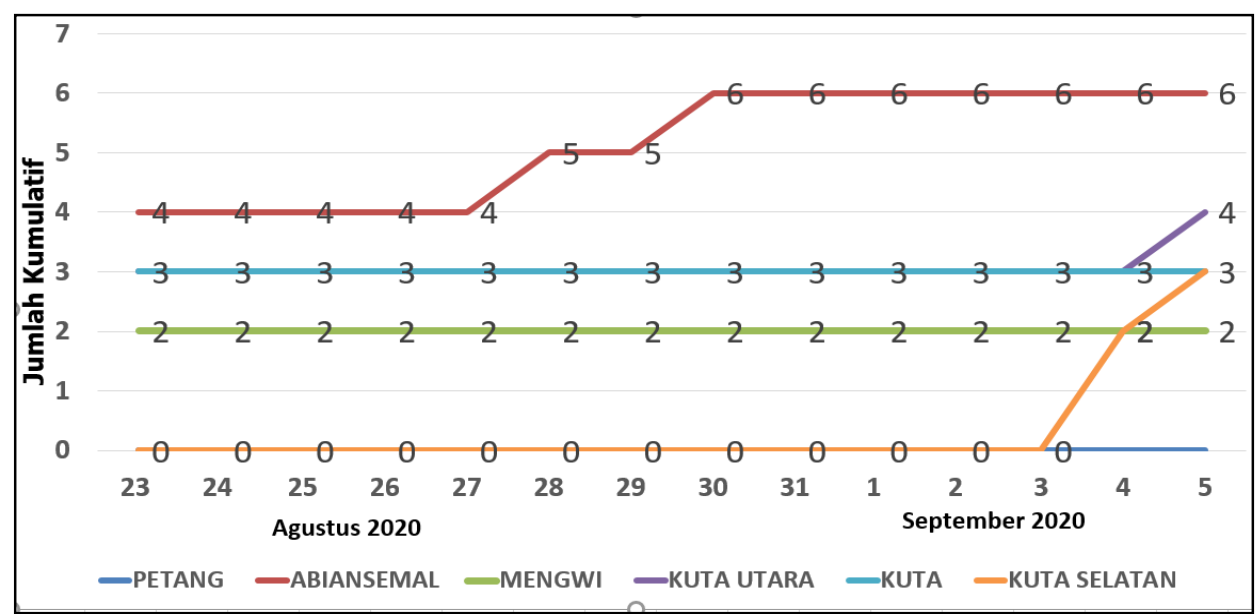

Gambar 2. Grafik Kasus Kematian Covid-19 di Kabupaten Badung Sumber: Data Satgas Covid-19 Kabupaten Badung yang diolah.

Gambar 2 menunjukan bahwa kasus kematian akibat Covid-19 paling banyak ditemukan di Kecamatan Abiansemal (6 orang), kemudian diikuti oleh Kuta Utara (4 orang), Kecamatan Kecamatan Kuta Selatan dan Kecamatan Kuta masingmasing 3 orang, Kecamatan Mengwi (2 orang), dan yang terakhir di Kecamatan Petang belum belum ada kasus kematian. 
Trend jumlah petugas kesehatan yang terpapar covid-19 di Kabupaten Badung dalam 14 hari, dari Tanggal 23 Agustus 2020 sampai dengan 5 September 2020 dapat dilihat pada grafik 3.

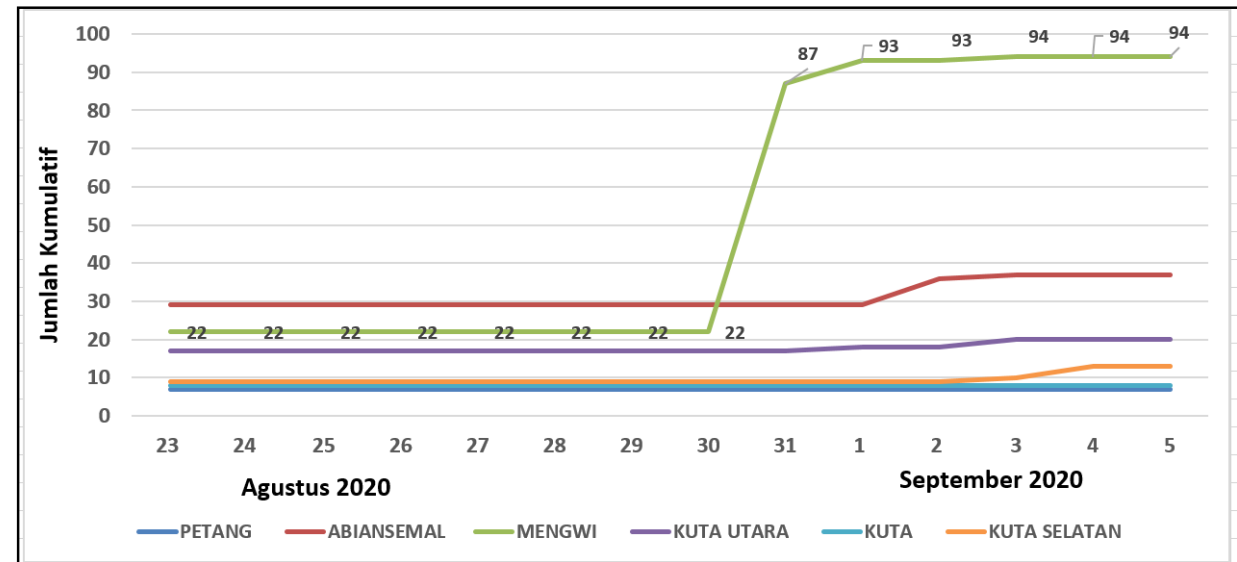

Gambar 3. Tenaga Kesehatan Terpapar Covid-19 di Kabupaten Badung Sumber: Data Satgas Covid-19 Kabupaten Badung yang diolah.

Berdasarkan hasil penilaian dan klasifikasi diperoleh peta Daerah Aspek Epidemiologi seperti terlihat pada gambar 4.

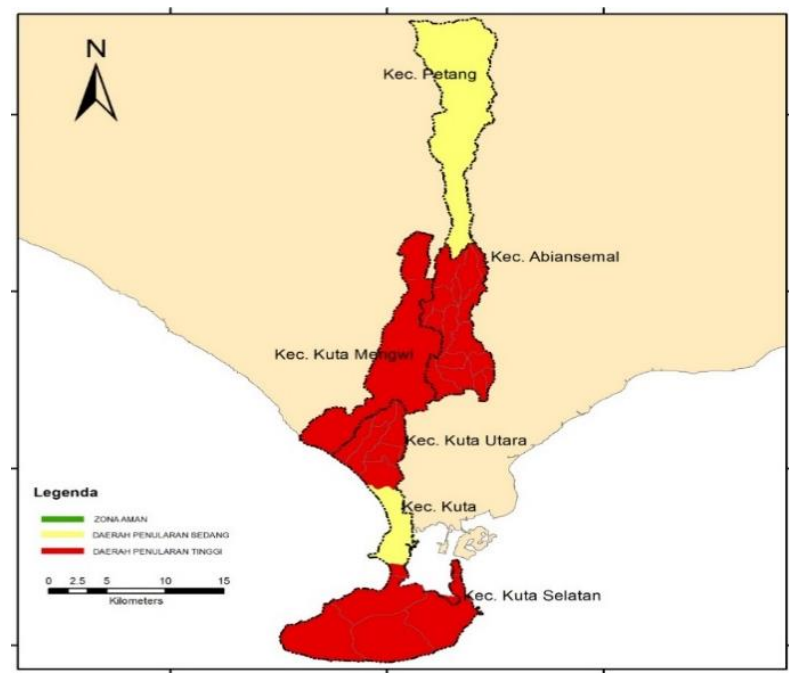

Gambar 4. Peta Epidemiologi Covid-19 di Kabupaten Badung Sumber: Data Satgas Covid-19 Kabupaten Badung yang diolah.

Dari Gambar 4 terlihat bahwa 4 kecamatan yaitu Kecamatan Abiansemal, Kecamatan Mengwi, Kecamatan Kuta Utara dan Kecamatan Kuta Selatan masuk kategori zona merah artinya daerah penularan tinggi dan 2 Kecamatan yaitu Kecamatan Petang dan Kecamatan Kuta masuk kategori zona kuning yang artinya daerah penularan sedang. 


\section{Aspek Respon Daerah Dalam Menangani Kasus Infeksi Covid-19}

Indikator penilaian untuk aspek Kemampuan Daerah Dalam Menangani Kasus Infeksi Covid-19 meliputi aspek Perlindungan Komunitas Masyarakat, Alat pelindung Petugas, Sarana Dan Peralatan Medis Lainnya, dan Perlengkapan Pasca Wafat.

Tabel 1. Rekapitulasi Hasil Penilaian Aspek Kemampuan Daerah Dalam Menangani Kasus Infeksi Covid-19 di Kabupaten Badung.

\begin{tabular}{|c|c|c|c|c|c|c|c|}
\hline No & Indikator & Petang & $\begin{array}{l}\text { Abian } \\
\text { Semal }\end{array}$ & Mengwi & $\begin{array}{l}\text { Kuta } \\
\text { Utara }\end{array}$ & Kuta & $\begin{array}{c}\text { Kuta } \\
\text { Selatan }\end{array}$ \\
\hline $\mathbf{A}$ & \multicolumn{7}{|c|}{ Pelindungan Komunitas Masyarakat } \\
\hline 1 & $\begin{array}{l}\text { Tempat cuci tangan dengan } \\
\text { sabun di tempat-tempat } \\
\text { publik }\end{array}$ & 100 & 100 & 100 & 100 & 100 & 100 \\
\hline 2 & $\begin{array}{l}\text { Hand Sanitaizer di ruang } \\
\text { publik }\end{array}$ & 100 & 100 & 100 & 100 & 100 & 100 \\
\hline 3 & $\begin{array}{l}\text { Hand Sanitaizer dalam } \\
\text { transportasi publik }\end{array}$ & 100 & 100 & 100 & 100 & 100 & 100 \\
\hline B & Alat Pelindung Petugas & & & & & & \\
\hline 1 & Alat Pelindung Diri & 100 & 100 & 100 & 100 & 100 & 100 \\
\hline 2 & Masker N95 & 100 & 100 & 100 & 100 & 100 & 100 \\
\hline 3 & $\begin{array}{l}\text { Sarung Tangan Karet } \\
\text { Untuk Examination } \\
\text { Sarung Tangan Karet }\end{array}$ & 100 & 100 & 100 & 100 & 100 & 100 \\
\hline 4 & Untuk Bedah & 100 & 100 & 100 & 100 & 100 & 100 \\
\hline 5 & $\begin{array}{l}\text { Helm Plastik Pelindung } \\
\text { Wajah }\end{array}$ & 100 & 100 & 100 & 100 & 100 & 100 \\
\hline $\mathbf{C}$ & Sarana Dan Peralatan I & Iedis Laiı & nya & & & & \\
\hline 1 & $\begin{array}{l}\text { Gedung untuk perwatan } \\
\text { khusus Covid-19 }\end{array}$ & 25 & 25 & 100 & 25 & 25 & 25 \\
\hline 2 & Rapid Test Kit & 100 & 100 & 100 & 100 & 100 & 100 \\
\hline 3 & $\begin{array}{l}\text { Sarung Tangan Karet } \\
\text { Untuk Examination }\end{array}$ & 100 & 100 & 100 & 100 & 100 & 100 \\
\hline D & Perlengkapan Pas & a Wafat & & & & & \\
\hline 1 & Kantong Plastik Mayat & 50 & 50 & 50 & 50 & 50 & 50 \\
\hline 2 & $\begin{array}{l}\text { Plastik untuk Pembungkus } \\
\text { Jenazah }\end{array}$ & 50 & 50 & 50 & 50 & 50 & 50 \\
\hline & TOT A L & $\mathbf{1 . 0 2 5}$ & 1.025 & 1.100 & $\mathbf{1 . 0 2 5}$ & 1.025 & 1.025 \\
\hline
\end{tabular}

Sumber: Data Satgas Covid-19 Kabupaten Badung yang diolah.

Pada tabel 1 nampak bahwa semua kecamatan masuk kategori Respon Tinggi dengan skor berkisar antara 850 - 1.200, sedangkan hasil pemetaan berdasarkan Aspek Kemampuan Daerah Dalam Menangani Kasus Infeksi Covid-19 di Kabupaten Badung menunjukan bahwa semua kecamatan masuk kategori Zona Hijau seperti terlihat pada gambar 5. 


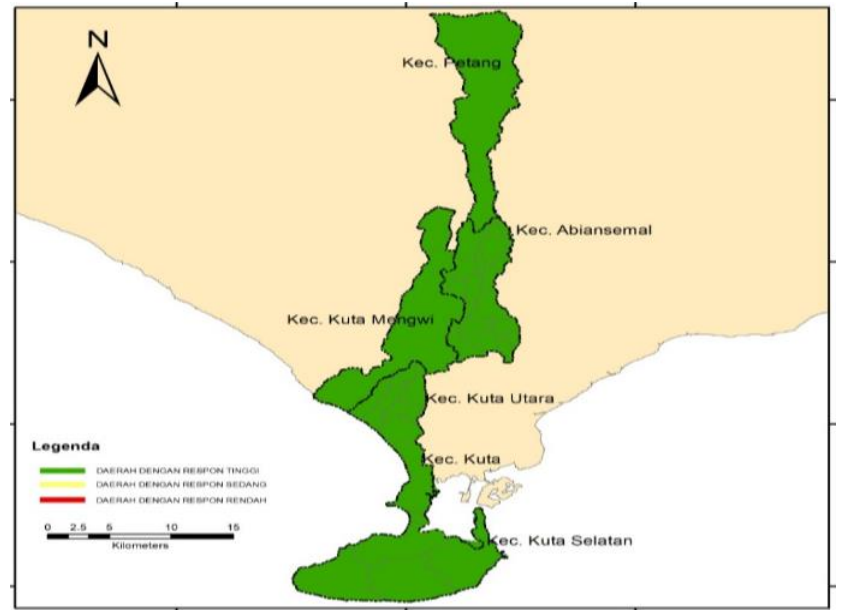

Gambar 5. Peta Respon Daerah Dalam Menangani Kasus Infeksi Covid-19 Sumber: Data Satgas Covid-19 Kabupaten Badung yang diolah.

\section{Aspek Kemampuan Daerah Dalam Melakukan Penelusuran Riwayat Kontak Dekat Orang Yang Terinfeksi Covid-19}

Indikator penilaian untuk aspek Kemampuan Daerah Dalam Melakukan Penelusuran Riwayat Kontak Dekat Orang Yang Terinfeksi Covid-19 dapat dilihat pada tabel 2.

Tabel 2 Aspek Kemampuan Daerah Dalam Melakukan Penelusuran Riwayat Kontak Dekat Orang Yang Terinfeksi Covid-19 di Kabupaten Badung

\begin{tabular}{|c|c|c|c|c|c|c|c|}
\hline No & Sub Indikator & Petang & $\begin{array}{l}\text { Abian } \\
\text { semal }\end{array}$ & Mengwi & $\begin{array}{c}\text { Kuta } \\
\text { Utara }\end{array}$ & Kuta & $\begin{array}{c}\text { Kuta } \\
\text { Selatan }\end{array}$ \\
\hline 1 & $\begin{array}{l}\text { Idantifikasi orang-orang yang } \\
\text { memiliki kontak dekat dengan } \\
\text { orang yang terindkasi Covid- } \\
19\end{array}$ & 100 & 50 & 100 & 50 & 100 & 50 \\
\hline 2 & $\begin{array}{l}\text { Informasi/data orang-orang } \\
\text { yang terinfeksi Covid-19 } \\
\text { akibat kontak dekat dengan } \\
\text { orang positif Covid-19 }\end{array}$ & 50 & 50 & 50 & 50 & 100 & 50 \\
\hline 3 & $\begin{array}{l}\text { Pengujian/test terhadap orang- } \\
\text { orang yang mempunyai kontak } \\
\text { dekat dengan orang-orang } \\
\text { yang terinfeksi Covid-19 }\end{array}$ & 100 & 50 & 100 & 50 & 50 & 50 \\
\hline 4 & $\begin{array}{l}\text { Penerapan dan monitoring } \\
\text { physical distancing }\end{array}$ & 50 & 50 & 50 & 25 & 50 & 25 \\
\hline & TOTAL SKOR & 300 & 200 & 300 & 175 & 300 & 175 \\
\hline
\end{tabular}

Sumber: Data Satgas Covid-19 Kabupaten Badung yang diolah. 
Pada tabel 2 terlihat bahwa 3 kecamatan yaitu Kecamatan Petang, Kecamatan Mengwi dan Kecamatan Kuta memperoleh skor 300, Kecamatan Abiansemal dgn skor 200 dan sisanya Kecamatan Petang kuta utara dan kuta selatan masing-masing mendapat skor 175 .

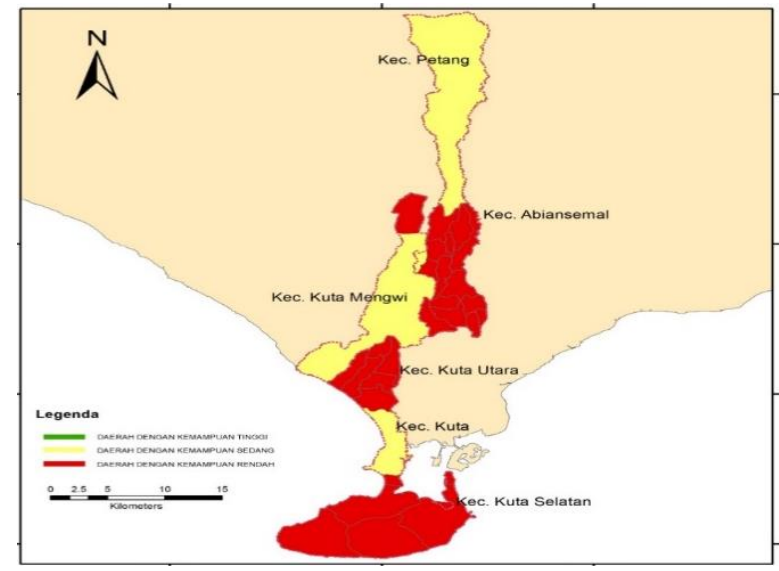

Gambar 6. Peta Penelusuran Riwayat Kontak Dekat Orang Yang Terinfeksi Covid-19 Sumber: Data Satgas Covid-19 Kabupaten Badung yang diolah.

Pada Gambar 6 terlihat bahwa 3 kecamatan yaitu Kecamatan Abiansemal, Kecamatan Kuta Utara dan Kecamatan Kuta Selatan masuk kategori kemampuan rendah dan 3 kecamatan lainnya yaitu Kecamatan Petang, Kecamatan Mengwi dan Kecamatan Kuta masuk kategori daerah dengan kemampuan sedang.

\section{PEMBAHASAN}

Sejak wisatawan domestik mulai berdatangan ke Bali pada awal bulan Agustus 2020, perlahan tapi pasti kasus covid mulai merangkak naik. Hasil penelitian Badr et al, 2020 menyatakan bahwa tingginya mobilitas masyarakat antar wilayah memfasilitasi meluasnya penyebaran Covid-19 dengan cepat. Pergerakan orang yang terinfeksi Coronavirus dari zona merah ke tempat lain lewat pesawat, kapal laut, dan transportasi darat berperan besar dalam penyebaran Covid19 (Noveria, 2020). Di sisi lain, keengganan masyarakat untuk stay at home menjadi tantangan tersendiri dalam pencegahan dan pengendalian penyebaran virus Covid-19 di masyarakat. Hal yang cukup menarik, hasil survei Dinas Perhubungan Kota Bandung Tahun 2020 terhadap masyarakat yang beraktifitas di luar rumah menunjukan bahwa hanya 20\% dari mereka yang merasa khawatir tertular virus Corona, sementara yang terbanyak adalah mereka khawatir kehilangan 
pekerjaan (62\%) dan 18\% sisanya khawatir penghasilannya berkurang (Kautsar, 2020).

Dari aspek epidemiologi menunjukan bahwa 4 kecamatan yaitu Kecamatan Abiansemal, Kecamatan Mengwi, Kecamatan Kuta Utara dan Kecamatan Kuta Selatan masuk kategori zona merah artinya daerah dengan risiko tinggi penularan Covid-19. Secara geografi, Kecamatan Abiansemal, Kecamatan Mengwi dan Kecamatan Kuta Utara berbatasan langsung dengan Kabupaten Gianyar, Kabupaten Tabanan dan Kota Denpasar. Menurut Prof Nyenswah (2020), di beberapa negara, lokasi geografis atau jumlah penduduk merupakan factor penting dan berpengaruh dalam penyebaran Covid-19. Demikian pula Wali Kota Depok menjelaskan bahwa salah satu penyebab warga Depok rawan tertular Covid-19 adalah karena letak geografis kota tersebut yang berbatasan langsung dengan DKI Jakarta, Tangerang, Bekasi dan Bogor (Lima, 2020).

Disampaing letak geografis, secara demografis 4 kecamatan zona merah merupakan daerah pusat perdagangan dengan volume penduduk yang relative padat. Kondisi ini berpotensi meningkatkan terjadinya penularan Covid-19. Hasil penelitian Wambrauw, 2020 di Kota Jaya Pura menyimpulkan bahwa kepadatan penduduk dan mobilitas penduduk menjadi salah salah satu factor peningkatan penyebaran Covid-19. Demikian pula hasil laporan Amindoni (2020) yang menunjukan bahwa Sejumlah pasar tradisional di Indonesia menjadi klaster baru penyebaran virus corona, setelah ratusan pedagang di sejumlah daerah, seperti Padang, Palangkaraya dan Jakarta, terinfeksi virus corona.

Tingginya angka kematian Covid-19 merupakan tantangan bagi semua fasilitas layanan kesehatan yang menangani pasien Covid-19. Hasil riset Kementerian Kesehatan menunjukkan bahwa sistem rujukan yang berbelit, pasien terlambat datang ke pusat pengobatan, diagnosis terlambat diberikan, pengobatan yang tidak adekuat serta ketidaktersediaan ventilator berpengaruh pada angka mortalitas di ICU (Suciatiningrum, 2020). Sedangkan menurut Anggota Tim Pakar Satuan Tugas Penanganan Covid-19, tingginya angka kematian akibat Covid-19 karena kebanyakan masyarakat baru pergi berobat ketika kondisinya sudah buruk, apalagi rumah sakit penuh sehingga petugas mengalami kesulitan, mana yang 
lebih dulu diprioritaskan. Faktor lain adalah penderita Covid-19 memiliki penyakit tidak menular seperti hipertensi, diabetes, dan penyakit jantung (Adimaja, 2020).

Terkait banyaknya petugas kesehatan yang terpapar Covid-19, pakar epidemiologi dari Fakultas Kesehatan Masyarakat (FKM) Universitas Indonesia Pandu Riono mengatakan bahwa faktor penyebab tenaga kesehatan (nakes) terpapar covid-19 adalah karena ketidaksiapan rumah sakit serta petugas medis berada di daerah yang tingkat penularannya sangat tinggi (Winahyu, 2020). Ketua Tim Pakar Gugus Tugas Percepatan Penanganan Covid-19 Wiku Adisasmito menyatakan bahwa banyak tenaga medis tidak sadar bahwa pasien yang mereka tangani positif covid-19 karena pasien tidak terbuka terkait riwayat kontak atau perjalanan mereka, sehingga tenaga medis tidak menerapkan protokol kesehatan yang ketat untuk mencegah penularan Prasetyo, (2020).

Pemerintah terus berupaya untuk menekan jumlah kasus covid-19. Salah satunya adalah melakukan realokasi dan refocusing anggaran untuk Penanganan Covid-19. Khusus bidang kesehatan, dana penanganan Covid-19 digunakan untuk pengadaan atau distribusi obat buffer stock, alat atau bahan pengendalian virus Corona, dan pengadaan alat pelindung diri (APD) untuk rumahsakit (RS). Selain itu, realokasi juga digunakan untuk pengadaan tes cepat corona, sosialisasi atau edukasi, serta pemeriksaan lab specimen (Kemenkeu RI, 2020).

Mengacu pada buku Pedoman Pencegahan Dan Pengendalian Coronavirus Disesase (Covid-19), prinsip dasar upaya penanggulangan Covid-19 bertumpu pada penemuan kasus suspek, yang dilanjutkan dengan upaya isolasi dan pemeriksaan laboratorium. Ketika hasil test RT-PCR positif dan pasien dinyatakan sebagai kasus konfirmasi, maka tindakan selanjutnya adalah pemberian terapi sesuai dengan protokol. Pelacakan kontak (trace) harus segera dilaksanakan segera setelah kasus suspek/probable ditemukan. Kontak erat akan dikarantina selama 14 hari. Jika setelah dilakukan karantina selama 14 hari tidak muncul gejala, maka pemantauan dapat dihentikan. Akan tetapi jika selama pemantauan, kontak erat muncul gejala maka harus segera diisolasi dan diperiksa swab (Kemenkes RI, 2020). 
Terkait dengan penelusuran kontak, kegiatan ini bukan perkara mudah karena dalam sehari seorang pasien bisa bertemu dengan banyak orang. Di samping itu, dengan terjadinya lonjakan kasus terkonfirmasi positif tim gugus tugas akan kewalahan melakukan penelusuran kontak. Sesuai dengan buku Pedoman Pencegahan Dan Pengendalian Covid-19, yang dimaksud dengan orang yang memiliki riwayat kontak dengan kasus konfirmasi Covid-19 adalah orang yang kontak tatap muka/berdekatan dengan orang terkonfirmasi dalam radius 1 meter dan dalam jangka waktu 15 menit atau lebih, sentuhan fisik langsung seperti bersalaman, berpegangan tangan, dan lain-lain, orang yang memberikan perawatan langsung terhadap pasien terkonfirmasi tanpa menggunakan APD, dan situasi lainnya yang mengindikasikan adanya kontak berdasarkan penilaian risiko lokal yang ditetapkan oleh tim penyelidikan epidemiologi (Rikin, 2020).

\section{SIMPULAN DAN SARAN}

Berdasarkan hasil pembahasan, maka dapat disimpulkan sebagai berikut:

1. Berdasarkan aspek epidemiologi: Zona Merah: Kec. Abiansemal, Mengwi, Kuta Utara dan Kuta Selatan. Zona Kuning: Kec. Petang dan Kuta Penangan Kasus Covid-19.

2. Berdasarkan Aspek Kemampuan Daerah Dalam Menangani Kasus Infeksi Covid-19, semua kecamatan merupakan daerah Zona Hijau.

3. Berdasarkan Aspek Kemampuan Daerah Dalam Melakukan Penelusuran Riwayat Kontak Dekat Orang Yang Terinfeksi Covid-19: Zona Merah: Kecamatan Abiansemal, Kecamatan Kuta Utara dan Kecamatan Kuta Selatan. Zona Kuning: Kecamatan Petang, Kecamatan Mengwi dan Kecamatan Kuta.

Adapun saran pada penelitian adalah sebagai berikut:

1. Untuk masyarakat yang berada pada daerah risiko penularan Covid-19 tinggi (zona merah) agar tidak bepergian, serta selalu menjalankan protokol kesehatan seperti penggunaan masker, cuci tangan, dan menjaga jarak aman.

2. Pada daerah zona merah Covid-19 agar dilakukan karantina wilayah terbatas pada wilayah tertentu (seperti banjar/RT/RW) untuk mencegah penyebaran penyakit semakin luas. 
3. Dalam melakukan sosialisasi serta edukasi publik agar melibatkan lembaga adat dan media massa setempat.

\section{DAFTAR PUSTAKA}

Adimaja, (2020), Satgas Jelaskan Penyebab Kematian Tinggi Terkait Corona.CNN Indonesia. Diakses dari : https://www.cnnindonesia.com/nasional/ 20200805131037-20-532406/satgas-jelaskan-penyebab-kematiantinggi-terkait-corona.

Amindoni, 2020, tuntutan perut, 'kalau nggak jualan, mau makan apa' kata pedagang. Diakses dari: https://www.bbc.com/indonesia/indonesia$\underline{53094297}$

Berita

https://news.google.com/covid19/map?hl=id\&gl=ID\&ceid=ID\%3Aid

Elyazar Iqbal, dkk., (2020), Mobilitas penduduk meluaskan zona merah COVID19: larangan mudik dari Jokowi harus diperkuat pengawasannya. Diakses dari: https://theconversation.com/mobilitas-penduduk-meluaskan-zonamerah-covid-19-larangan-mudik-dari-jokowi-harus-diperkuatpengawasannya-136681

Firmansyah, Rian (2020), Survei PSBB Dishub Kota Bandung: Kesadaran Masyarakat Akan Bahaya Corona Masih Rendah. Diakses dari: https://prfmnews.pikiran-rakyat.com/mapay-kota/pr-13377182/surveipsbb-dishub-kota-bandung-kesadaran-masyarakat-akan-bahaya-coronamasih-rendah?page $=3$.

Kurniandari, Rohmana (2020), UPDATE Sebaran Virus Corona Indonesia, Diakses dari: https://ternate.tribunnews.com/2020/09/12/update-sebaran-viruscorona-indonesia-sabtu-1292020-tambah-3806-kasus-baru-1205-daridki.

Kemenkeu RI, (2020), Pemantauan dan Evaluasi atas Realokasi dan Refocusing APBD untuk Penanganan COVID-19 di Daerah. Diakses dari: https://www.kemenkeu.go.id/publikasi/siaran-pers/siaran-perspemantauan-dan-evaluasi-atas-realokasi-dan-refocusing-apbd-untukpenanganan-covid-19-di-daerah/. 
Kautsar, (2020), Hasil Survei Dishub Sebut Warga Bandung Lebih Takut Gak Kerja Dibanding Corona. Diakses dari: https://www.merdeka.com/jabar/hasilsurvei-dishub-sebut-warga-bandung-lebih-takut-gak-kerja-dibandingcorona.html.

Kemenkes RI, (2020), Pedoman Pencegahan dan Pengendalian Covid-19. Revisi ke-5.

Lima, L, (2020), Virus corona: Lima strategi sukses yang dipakai berbagai negara untuk kendalikan covid-19. BBC News Mundo. Diakses dari: https://www.bbc.com/indonesia/ majalah-51974072.

Noveria, Mita, (2020), Mobilitas Orang dan Penularan COVID-19. Diakses dari: https://kependudukan.lipi.go.id/id/berita/53-mencatatcovid19/880mobilitas-orang-dan-penularan-covid-19.

Prasetyo, (2020), Ini Penyebab Tenaga Medis Terpapar Covid-19 Andhika. Diakses dari: https://mediaindonesia.com/read/detail/310805-ini-penyebabtenaga-medis-terpapar-covid-19.

Rikin, (2020), Penelusuran Kontak Agresif, Laporan Kasus Positif Covid-19 Naik. Diakses dari: https://www.beritasatu.com/yudodahono/nasional/645401/ penelusuran- kontak-agresif-laporan-kasuspositif-covid19-naik.

Suciatiningrum, (2020), Ini Penyebab Tingginya Kematian Pasien COVID-19 di ICU RS di Indonesia.Diakses dari : https://banten.idntimes.com/ news/indonesia/dini-

Winahyu, (2020), Ini Penyebab Tenaga Medis Rentan Terpapar Covid-19. Diakses dari: $\quad$ https://mediaindonesia.com/read/detail/333310-ini-penyebabtenaga-medis-rentan-terpapar-covid-19.

Wambrauw, 2020, Korelasi Kepadatan Penduduk dan Penyebaran COVID-19 di Kota Jayapura. Diakses dari: $\quad$ https://kependudukan.lipi.go.id/id/berita/53mencatatcovid19/1037-korelasi-kepadatan-penduduk-dan-penyebarancovid-19-di-kota-jayapura. 